\title{
Rhombohedral boron nitride epitaxy on $\mathrm{ZrB}_{2}$
}

Cite as: J. Vac. Sci. Technol. A 39, 013405 (2021); https://doi.org/10.1116/6.0000571

Submitted: 21 August 2020 . Accepted: 20 November 2020 . Published Online: 21 December 2020

(D) Laurent Souqui, (D) Justinas Palisaitis, Naureen Ghafoor, (D) Henrik Pedersen, and (iD) Hans Högberg
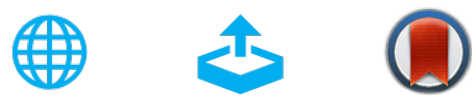

View Online

\section{ARTICLES YOU MAY BE INTERESTED IN}

Surface ligand removal in atomic layer deposition of GaN using triethylgallium

Journal of Vacuum Science \& Technology A 39, 012411 (2021); https://

doi.org/10.1116/6.0000752

Chemical vapor deposition of $\mathrm{sp}^{2}$-boron nitride on $\mathrm{Si}(111)$ substrates from triethylboron and ammonia: Effect of surface treatments

Journal of Vacuum Science \& Technology A 38, 043402 (2020); https://

doi.org/10.1116/1.5145287

Modified atomic layer deposition of $\mathrm{MoS}_{2}$ thin films

Journal of Vacuum Science \& Technology A 38, 060403 (2020); https://

doi.org/10.1116/6.0000641

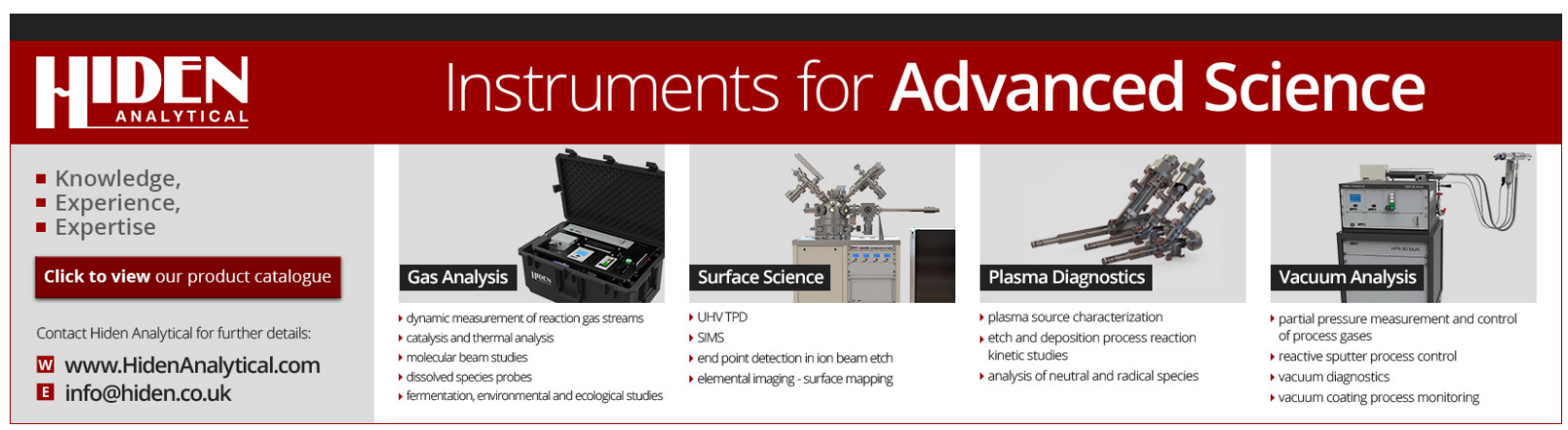




\title{
Rhombohedral boron nitride epitaxy on $\mathrm{ZrB}_{2}$
}

Cite as: J. Vac. Sci. Technol. A 39, 013405 (2021); doi: $10.1116 / 6.0000571$

Submitted: 21 August 2020 . Accepted: 20 November 2020 .

Published Online: 21 December 2020

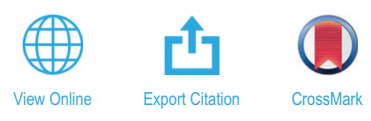

Laurent Souqui, (D) Justinas Palisaitis, (D) Naureen Ghafoor, Henrik Pedersen, (D) and Hans Högberg ${ }^{\text {a }}$

AFFILIATIONS

Department of Physics, Chemistry and Biology (IFM), Linköping University, SE-581 83 Linköping, Sweden

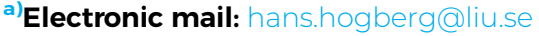

\begin{abstract}
Epitaxial rhombohedral boron nitride ( $\mathrm{r}-\mathrm{BN})$ films were deposited on $\mathrm{ZrB}_{2}(0001) / 4 \mathrm{H}-\mathrm{SiC}(0001)$ by chemical vapor deposition at $1485^{\circ} \mathrm{C}$ from the reaction of triethylboron and ammonia and with a minute amount of silane $\left(\mathrm{SiH}_{4}\right)$. X-ray diffraction (XRD) $\varphi$-scans yield the epitaxial relationships of $\mathrm{r}-\mathrm{BN}(0001) \| \mathrm{ZrB}_{2}(0001)$ out-of-plane and $\mathrm{r}-\mathrm{BN}[11 \overline{2} 0] \| \mathrm{ZrB}_{2}[11 \overline{2} 0]$ in-plane. Cross-sectional transmission electron microscopy (TEM) micrographs showed that epitaxial growth of $\mathrm{r}$-BN films prevails to $\sim 10 \mathrm{~nm}$. Both XRD and TEM demonstrate the formation of carbon- and nitrogen-containing cubic inclusions at the $\mathrm{ZrB}_{2}$ surface. Quantitative analysis from $\mathrm{x}$-ray photoelectron spectroscopy of the $\mathrm{r}-\mathrm{BN}$ films shows $\mathrm{B} / \mathrm{N}$ ratios between 1.30 and 1.20 and an $\mathrm{O}$ content of 3-4 at. \%. Plan-view scanning electron microscopy images reveal a surface morphology where an amorphous material comprising $\mathrm{B}, \mathrm{C}$, and $\mathrm{N}$ is surrounding the epitaxial twinned r-BN crystals.
\end{abstract}

Published under license by AVS. https://doi.org/10.1116/6.0000571

\section{INTRODUCTION}

Given a bandgap in UV $(5.9 \mathrm{eV})$, the $\mathrm{sp}^{2}$-hybridized forms of boron nitride $\left(\mathrm{sp}^{2}-\mathrm{BN}\right){ }^{1}$ hexagonal $\mathrm{BN}$ (h-BN), and rhombohedral $\mathrm{BN}(\mathrm{r}-\mathrm{BN})$ are promising thin film materials for application in UV-optoelectronics. As for the other 13-15 (formerly denoted as III-V) semiconductor materials AlN, GaN, and InN, chemical vapor deposition (CVD) is a suitable thin film synthesis route for $\mathrm{sp}^{2}-\mathrm{BN}$. However, deposition of crystalline $\mathrm{sp}^{2}-\mathrm{BN}$ films by thermal CVD often requires deposition temperatures above $1200{ }^{\circ} \mathrm{C}^{2-9}$ This limits the choice of substrate materials for epitaxy seen from demonstrated growth on $3 \mathrm{C}-\mathrm{SiC}(111), 4 \mathrm{H}-$ and $6 \mathrm{H}-\mathrm{SiC}(0001)$, and $\mathrm{Al}_{2} \mathrm{O}_{3}(0001)$.

From this perspective, zirconium diboride $\left(\mathrm{ZrB}_{2}\right)$ with a hexagonal $\mathrm{AlB}_{2}$-type structure ${ }^{10}$ is an interesting alternative seen from a melting point of $3245^{\circ} \mathrm{C}$ that is favorable in hightemperature CVD processes. It also demonstrates a high chemical stability $^{11}$ to withstand corrosive gases such as hydrogen $\left(\mathrm{H}_{2}\right)$, ammonia $\left(\mathrm{NH}_{3}\right)$, triethylboron [TEB, $\mathrm{B}\left(\mathrm{C}_{2} \mathrm{H}_{5}\right)_{3}$ ], or silane $\left(\mathrm{SiH}_{4}\right)$ typically applied as precursors in $\mathrm{CVD}$. The low electrical resistivity $7.0 \times 10^{-6} \Omega \mathrm{cm}$ (Ref. 12) of $\mathrm{ZrB}_{2}$ as well as high reflectivity and low absorption between 5 and $6 \mathrm{eV}$ (Ref. 13) make it promising as an electrical contact for UV-devices. A further benefit is that epitaxial $\mathrm{ZrB}_{2}$ films can be deposited by direct current magnetron sputtering (DCMS) on the substrates typically applied in $\mathrm{CVD}$ of $\mathrm{sp}^{2}-\mathrm{BN}$ films, i.e., $\mathrm{Al}_{2} \mathrm{O}_{3}(0001)^{14}$ and $4 \mathrm{H}-\mathrm{SiC}(0001) .^{15,16}$
Comparing the in-plane lattice parameters of $h$ - and $r-B N$ $(\mathrm{a}=2.504 \AA)$ and of $\mathrm{ZrB}_{2}(3.168 \AA)$, the relative mismatch of $\mathrm{sp}^{2}-\mathrm{BN}$ to $\mathrm{ZrB}_{2}$ is relatively high $(-21.0 \%)$, but from a "magic mismatch" with five $\mathrm{sp}^{2}$ - $\mathrm{BN}$ unit cells over four $\mathrm{ZrB}_{2}$ unit cells, it decreases down to $-1.2 \%$.

The literature shows that other 13-15 semiconductor materials such as $\mathrm{GaN}$ have been deposited on bulk $\mathrm{ZrB}_{2}$ substrates ${ }^{17-23}$ and $\mathrm{ZrB}_{2}$ thin films deposited by thermal decomposition of $\mathrm{Zr}\left(\mathrm{BH}_{4}\right)_{4}$ on $\mathrm{Si}(111)$ at $900^{\circ} \mathrm{C}$ in $\mathrm{UHV} .^{24,25} \mathrm{In}$ a recent publication, Padavala et al. deposited films of BP by CVD from diborane $\left(\mathrm{B}_{2} \mathrm{H}_{6}\right)$ and phosphine $\left(\mathrm{PH}_{3}\right)$ deposited at temperatures of 1000,1100 , and $1200^{\circ} \mathrm{C}$ on epitaxial $\mathrm{ZrB}_{2}$ thin films. ${ }^{26}$ In this work, we investigate CVD of $\mathrm{sp}^{2}-\mathrm{BN}$ films from TEB $\left[\mathrm{B}\left(\mathrm{C}_{2} \mathrm{H}_{5}\right)_{3}\right]$ and $\mathrm{NH}_{3}$ at $1485^{\circ} \mathrm{C}$, using $\sim 300 \mathrm{~nm}$ thick epitaxial $\mathrm{ZrB}_{2}$ films deposited by DCMS on $4 \mathrm{H}-\mathrm{SiC}(0001)$ substrates and where the choice of substrate material resulted in $\mathrm{ZrB}_{2}$ films free of crystal twinning. ${ }^{15}$

\section{EXPERIMENTAL DETAILS}

The epitaxial $\mathrm{ZrB}_{2}(0001)$ films applied as templates in the growth of the $\mathrm{BN}$ films were deposited on three $4 \mathrm{H}-\mathrm{SiC}(0001)$ substrates by DCMS of a $\mathrm{ZrB}_{2}$ compound target of $99.5 \%$ purity (excluding Hf) from Kurt J. Lesker Company Ltd that are henceforth referred to as samples 1,2, and 3. The sputter process was carried out in an ultrahigh vacuum system at a base pressure below 
$1.6 \times 10^{-6} \mathrm{~Pa}$ in an argon (99.9997\%) plasma held at $0.53 \mathrm{~Pa}$, using a magnetron power of $400 \mathrm{~W}$ to the circular target with a diameter of $3 \mathrm{in}$. and at a substrate temperature of $900^{\circ} \mathrm{C}$. Growth at these conditions during 5 min resulted in $\mathrm{ZrB}_{2}$ film thicknesses between 250 and $300 \mathrm{~nm}$. A more detailed description of the sputtering conditions can be found in Ref. 15. Pole figure measurements showed an epitaxial relationship of $\mathrm{ZrB}_{2}(0001) \| 4 \mathrm{H}-\mathrm{SiC}(0001)$ and $\mathrm{ZrB}_{2}[1 \overline{1} 00] \| 4 \mathrm{H}-\mathrm{SiC}[1 \overline{1} 00]$ between the film and the substrate, i.e., the $\mathrm{ZrB}_{2}$ films were free of twinning. ${ }^{15}$

The boron nitride films were deposited on the templates from the reactants TEB and $\mathrm{NH}_{3}$ in a hot-wall horizontal CVD reactor with a base pressure below $10^{-5} \mathrm{~Pa}$ at a temperature of $1485^{\circ} \mathrm{C}$ and a pressure of $7000 \mathrm{~Pa}$, using a growth time of $120 \mathrm{~min}$. The process was performed by reacting 0.7 SCCM TEB ( $99.99 \%$ purity, SAFC

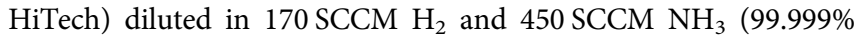
purity) in 5000 SCCM hydrogen $\left(\mathrm{H}_{2}, 99.9996 \%\right.$ purity, further purified by a palladium-membrane) and with 0.026 SCCM silane $\left(\mathrm{SiH}_{4}, 99.999 \%\right.$ purity, 2000ppm diluted in 99.9996\%-purity $\left.\mathrm{H}_{2}\right)$. The TEB was diluted with a separate quartz liner to avoid the possibility of the formation of an $\mathrm{NH}_{3}: \mathrm{B}\left(\mathrm{CH}_{2} \mathrm{CH}_{5}\right)_{3}$ adduct ${ }^{27,28}$ prior to reaching the hot zone. The process pressure was regulated by a throttle valve and the deposition temperature was monitored by a pyrometer (Heitronics KT81R, calibrated by silicon melting).

As the epitaxial $\mathrm{ZrB}_{2}(0001)$ films had been stored in air for some time, degreasing and removal of surface oxide were necessary; the thickness of the surface oxide was previously determined to be about $11 \AA$ by x-ray photoelectron spectroscopy (XPS) analysis. The epitaxial $\mathrm{ZrB}_{2}(0001)$ films applied as growth templates were as a first step degreased in an ultrasonic bath in acetone and in ethanol for $3 \mathrm{~min}$ each. As a second step and attempting pretreatment by dipping in aqueous HF was proven to be insufficient to allow for growth of BN films with a good crystal quality, see $2 \theta / \omega$ diffractogram in Fig. S1 in the supplementary material ${ }^{48}$ with no visible peaks originating from $\mathrm{sp}^{2}-\mathrm{BN}$. Therefore, following degreasing, the epitaxial $\mathrm{ZrB}_{2}(0001)$ films were inserted in the CVD reactor cell, heated to $1485^{\circ} \mathrm{C}$ and then stabilized in $5000 \mathrm{SCCM} \mathrm{H}_{2}$ for $3 \mathrm{~min}$. From our previous experience demonstrating epitaxial growth of $\mathrm{sp}^{2}-\mathrm{BN}$ on $\alpha-\mathrm{Al}_{2} \mathrm{O}_{3}(0001)$ and $6 \mathrm{H}-\mathrm{SiC}(0001)$ substrates, ${ }^{29}$ we have shown that a small flow of $\mathrm{SiH}_{4}$ added prior to and during deposition improved the crystalline quality of the $\mathrm{sp}^{2}-\mathrm{BN}$ film. ${ }^{30}$ Thus, this practice was applied when using epitaxial $\mathrm{ZrB}_{2}(0001)$ as substrates. The templates were pretreated as follows to remove the surface oxide:

- Sample 1: exposed to $0.026 \mathrm{SCCM} \mathrm{SiH}_{4}$ and $5000 \mathrm{SCCM} \mathrm{H}_{2}$ for $2 \mathrm{~min}$

- Sample 2: exposed to $0.026 \mathrm{SCCM} \mathrm{SiH}_{4}$ and $5000 \mathrm{SCCM} \mathrm{H}_{2}$ for $15 \mathrm{~min}$

- Sample 3: exposed to $0.026 \mathrm{SCCM} \mathrm{SiH}_{4}$ and $5000 \mathrm{SCCM} \mathrm{H}_{2}$ for $60 \mathrm{~min}$

The structural properties of $\mathrm{BN}$ films and their crystallographic relationship to the $\mathrm{ZrB}_{2}$ buffer layer were characterized by thin film $\mathrm{x}$-ray diffraction (XRD). A PANalytical X'Pert PRO diffractometer was used to acquire $2 \theta / \mathrm{w}$ diffractograms (Bragg-Brentano HD mirror with $1 / 2^{\circ}$ divergence on the primary side, X'Celerator detector with a $0.5 \mathrm{~mm}$ antiscatter slit, 0.04 rad Soller slits, and nickel $\mathrm{K} \alpha$ filter on the secondary side). A Phillips X'Pert MPD diffractometer, with cross-slits $\left(2 \times 2 \mathrm{~mm}^{2}\right)$ and nickel $\mathrm{K} \alpha$ filter on the primary side and a proportional detector (PW1711/96) equipped with a parallel plate collimator on the secondary side was used to record grazing-incidence diffractograms (GIDs) and $\varphi$-scans.

The surface morphology of the BN films was assessed by scanning electron microscopy (SEM, Gemini). The microscope was operated with conventional and immersion lens (in-lens) secondary electron detectors and an accelerating voltage of $5 \mathrm{kV}$.

XPS was used to investigate the chemical bonding structure and the composition of the films as well as to measure the thickness of the surface oxide on the $\mathrm{ZrB}_{2}(0001)$ template. The instrument Kratos Analytical AXIS Ultra DLD operated at a base pressure of $1.5 \times 10^{-7} \mathrm{~Pa}$ and the $\mathrm{x}$-ray anode (monochromatic $\mathrm{Al}$ $\mathrm{K} \alpha$ radiation, $1486.6 \mathrm{eV}$ ) was operated at $225 \mathrm{~W}$. The binding energy scale was calibrated by setting the position of the Fermi edge of a sputter-cleaned $\mathrm{Ag}$ sample to $0.0 \mathrm{eV}$ (Ref. 31) resulting in the position of the $\mathrm{Ag} 3 \mathrm{~d}_{5 / 2}$ core-level peak of $368.30 \mathrm{eV}^{32}$ The samples were analyzed after sputter-cleaning for $700 \mathrm{~s}$ with $4 \mathrm{keV}$ Ar-ions incident at an angle of $70^{\circ}$ with respect to the surface normal to remove adsorbed contaminants following air exposure. The CASAXPS software (version 2.3.13) was used to analyze the XPS data. The quantification accuracy of XPS is typically around $\pm 5 \% .{ }^{33}$

High-resolution TEM (HRTEM) imaging and electron energy loss spectroscopy (EELS) analyses were performed in the doublecorrected Linköping FEI $\operatorname{Titan}^{3} 60-300$, operated at $300 \mathrm{kV}$. The microscope is equipped with a monochromated X-FEG highbrightness gun, an efficient high solid angle Super-X Energy dispersive s-ray detector, and an ultrafast Gatan GIF Quantum ERS postcolumn imaging filter. HRTEM images were recorded under negative spherical aberration imaging conditions with slight positive defocus, both ensuring high-resolution images with bright-atom contrast. ${ }^{34}$ EELS spectrum images of $50 \times 50$ pixels were acquired for $1 \mathrm{~min}$ using a $0.25 \mathrm{eV} /$ channel energy dispersion, $0.2 \mathrm{~s}$ pixel dwell time, and a collection semi-angle of $55 \mathrm{mrad}$. Elemental B, C, and $\mathrm{N}$ distribution maps/profiles were extracted from EELS spectrum images by background subtraction, using a power law, and choosing characteristic edges B-K (188-200 eV), C-K (284-310 eV), and N-K (401-430 eV) energy loss integration windows.

Cross-sectional TEM lamella was prepared using focused ion beam (Carl Zeiss Cross-Beam 1540 EsB system).

\section{RESULTS AND DISCUSSION}

\section{A. Boron chemical bonding state and composition of the films}

Figure 1 shows high-resolution B 1s XPS spectra from the BN films deposited on samples 1, 2, and 3 following $700 \mathrm{~s} \mathrm{Ar}^{+}$sputtercleaning. For all investigated samples, the B 1s spectra present a peak centered around $190.2-190.6 \mathrm{eV}$, corresponding to B-N bonding. ${ }^{32,35}$ These peaks show that BN has nucleated on samples 1 , 2, and 3. This is supported from high-resolution N 1s XPS spectra, not shown, with single peaks positioned at $397.8 \mathrm{eV}$ from N-B bonding. ${ }^{35}$ In addition, the weak peaks present at around $200 \mathrm{eV}$ can be ascribed to $\pi$-plasmons that support the presence of $\mathrm{sp}^{2}-\mathrm{BN}$ in samples 1 and $2 .^{35}$ Sample 3 displays additional peaks with one peak at $188.0 \mathrm{eV}$ and a doublet peak 178.5 and $180.9 \mathrm{eV}$. The peaks originate from $\mathrm{B}-\mathrm{Zr}$ bonding as determined from $\mathrm{B} 1 \mathrm{~s}$ photoelectrons at 

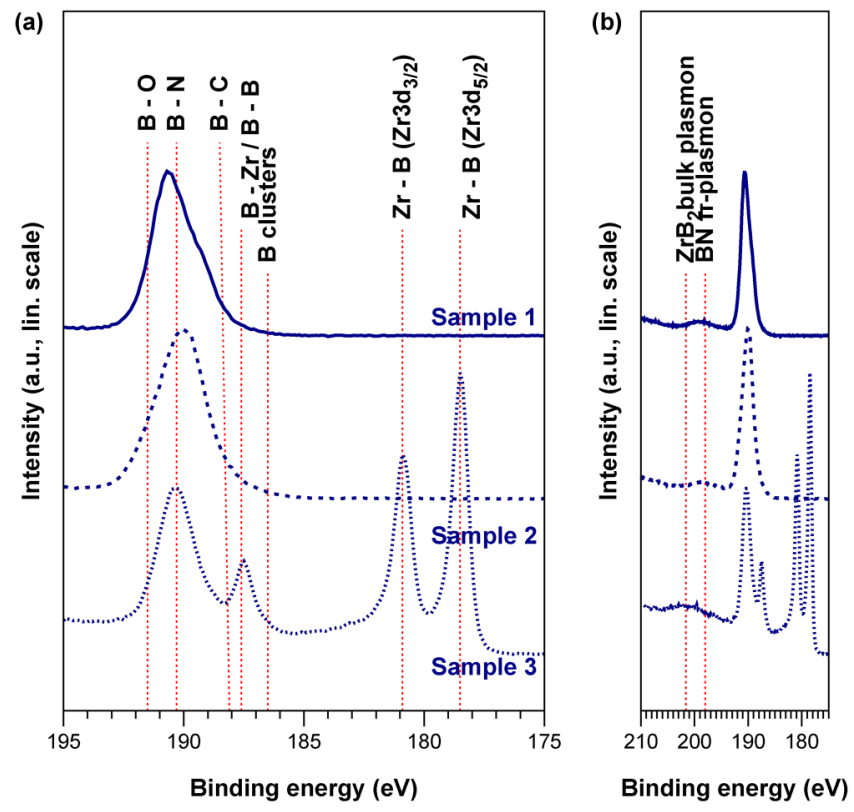

FIG. 1. (a) High-resolution B 1s XPS spectra recorded from BN films deposited on samples 1, 2, and 3 after $700 \mathrm{~s}$ Ar sputter-cleaning. (b) Rescaled spectra at the binding energies of the $\mathrm{BN} \pi$-plasmon and $\mathrm{ZrB}_{2}$ bulk plasmon. Literature binding energies for B-N (Refs. 32 and 35 ), B-Zr and $\mathrm{Zr}-\mathrm{B}$ (Refs. 16 and 36 ), and B-O (Refs. 32 and 37). B-B (Ref. 32), B-clusters (Refs. 38-40), B-C (Refs. $39-41$ ), and plasmons (Refs. 13 and 35 ) are indicated by vertical dotted lines.

$188.0 \mathrm{eV}$ and from $\mathrm{Zr} 3 \mathrm{~d}$ photoelectrons at 179.1 and $181.4 \mathrm{eV}$, respectively. ${ }^{36}$ The binding energies of the peaks agree with those previously determined by Tengdelius et al. for an epitaxial $\mathrm{ZrB}_{2}$ film deposited on a $4 \mathrm{H}-\mathrm{SiC}(0001)$ substrate. ${ }^{16}$ The appearance of these peaks in the spectrum suggests that the BN film on sample 3 has been partly sputtered through. For sample 3, there is an apparent shift of the $\pi$-plasmon peak toward higher energy that is due to the presence of the bulk plasmon peak of $\mathrm{ZrB}_{2}$. ${ }^{13}$

In addition, XPS was applied for quantitative analysis of the deposited BN film, see Table I. From the determined compositions, it is evident that all the deposited films are boron rich and with the highest $\mathrm{B} / \mathrm{N}$ ratio of 1.30 determined for sample 1 followed by sample 2 with 1.25 , and finally sample 3 with 1.20 . Thus, samples 1 , 2 , and 3 show decreasing $\mathrm{B} / \mathrm{N}$ ratio, while sample 3 exhibits a slightly higher nitrogen content. Here, we note the limited thickness for sample 3 that may affect the $\mathrm{B} / \mathrm{N}$ ratio. The oxygen content was determined to $2.9,4.4$, and 2.7 at. \% with the lowest in sample 3 and

TABLE I. Composition of the BN films surface as determined by XPS.

\begin{tabular}{lccccc}
\hline \hline Sample No. & at. \% B & at. \% N & B/N ratio & at. \% O & at. \% C \\
\hline Sample 1 & 49.0 & 37.8 & 1.30 & 2.9 & 10.1 \\
Sample 2 & 47.4 & 37.9 & 1.25 & 4.4 & 10.2 \\
Sample 3 & 51.6 & 43.1 & 1.20 & 2.7 & 2.2 \\
\hline \hline
\end{tabular}

the highest content in sample 2. The carbon content in samples 1 and 2 are $\sim 10$ at. \%, but only $\sim 2$ at. \% in sample 3 . Figure 1 shows no visible peaks that can be assigned to boron clusters ${ }^{38-40}$ or B-C bonding seen from reported binding energies in the range of 188.1$188.6 \mathrm{eV},{ }^{39-41}$ but with tails on the $\mathrm{B}-\mathrm{N}$ peaks for samples 1 and 2 that can be assigned to $\mathrm{B}-\mathrm{C}$ bonding.

Furthermore, the $\mathrm{C} 1 \mathrm{~s}$ spectra obtained from samples 1 and 2, not shown, demonstrate peaks from C-C bonding at $284.3 \mathrm{eV}$ and to carbon bonded to at least one boron at $282.4-282.8 \mathrm{eV} .{ }^{40}$ In determination of the carbon and the oxygen content, we submit to the fact that the BN films had been exposed to air prior to analysis rendering sputter-cleaning of the surface of the BN film necessary. In XPS, $\mathrm{Ar}^{+}$sputter-cleaning can introduce artifacts such as preferential sputtering and forward implantation to cause an enrichment of elements such as carbon and oxygen. ${ }^{42}$

\section{B. Thin film x-ray diffraction}

Figure 2 shows the $2 \theta / \omega$ diffractogram from the BN film deposited on sample 1 . The relatively weak diffraction peaks at $2 \theta=26.7^{\circ}$ and $2 \theta \approx 55^{\circ}$ originate from $\mathrm{sp}^{2}-\mathrm{BN}(000 \ell)$ and $\mathrm{sp}^{2}-\mathrm{BN}$ $(0002 \ell),{ }^{43-45}$ respectively, and where the hki $\ell$ of the peaks are indicative of long-range order in the direction normal to the template surface. Samples 2 and 3 display similar XRD patterns as sample 1, albeit with lower intensities for the $\mathrm{BN}$ peaks.

GID scans along $\mathrm{ZrB}_{2}$ [11 $\left.\overline{2} 0\right]$ and $\mathrm{ZrB}_{2}$ [10 $\left.\overline{1} 0\right]$ were recorded, see Figs. 3(a) and 3(b), respectively. In Fig. 3(a), the diffractogram along $\mathrm{ZrB}_{2}$ [112̄0] shows peaks at $2 \theta=75.9^{\circ}$ that is the $11 \overline{2} 0$ peak from $\mathrm{r}-\mathrm{BN}$ or h-BN, as this family of plane is shared by both polytypes. The diffractogram along $\mathrm{ZrB}_{2}$ [1010] allows us to distinguish both polytypes as the $\{k 0 k 0\}$ planes of $\mathrm{r}-\mathrm{BN}$ are extinct unlike those of h-BN. As there is no evident $10 \overline{1} 0$ peak from $h-B N$ at $2 \theta=41.6^{\circ}$, we can conclude that $\mathrm{r}-\mathrm{BN}$ films were grown. The low intensity peak at $75.9^{\circ}$ in Fig. 3(b) can be attributed to a minor twinning of $\mathrm{r}-\mathrm{BN}$ (grains rotated $30^{\circ}$ ).

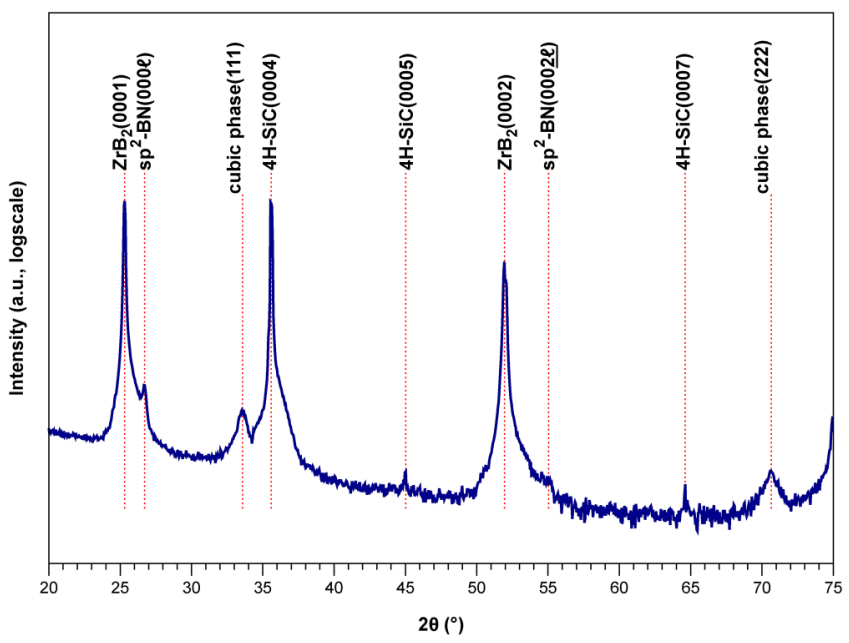

FIG. 2. $2 \theta / \omega$ diffractogram from the BN film deposited on sample 1 . 

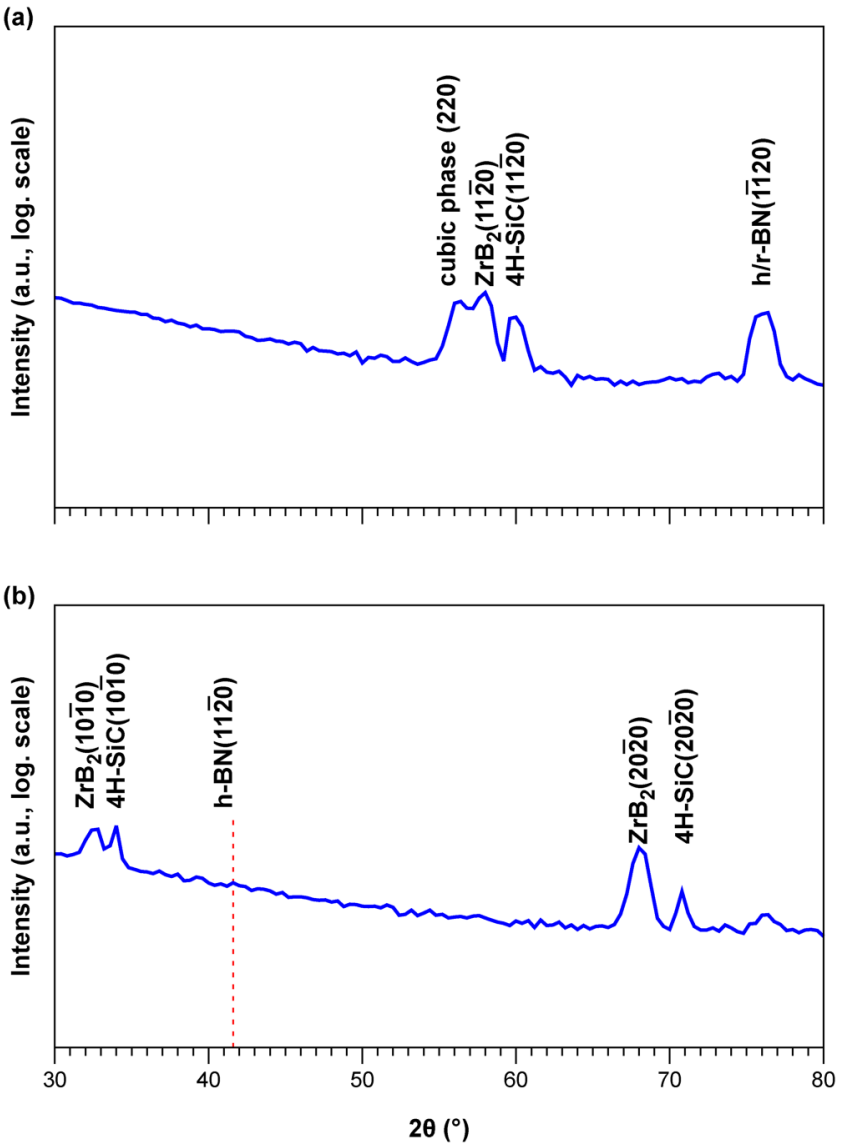

FIG. 3. GID diffractogram of sample 1 along (a) $\mathrm{ZrB}_{2}[11 \overline{2} 0]$ suggesting the epitaxial relationship between $\mathrm{sp}^{2}-\mathrm{BN}$ and $\mathrm{ZrB}_{2}$ and (b) $\mathrm{ZrB}_{2}$ [1010] showing that $\mathrm{h}-\mathrm{BN}$ is not detected.

Epitaxial growth relationships of $\mathrm{r}$-BN were determined by $\varphi$-scans conducted on samples 1 and 2 in Fig. 4. Besides showing the orientation of $\mathrm{r}$-BN with respect to the template, the $\varphi$-scans in Fig. 4 show the twinning of $\mathrm{r}-\mathrm{BN}$. The epitaxial relationships between the $\mathrm{r}-\mathrm{BN}$ film, the $\mathrm{ZrB}_{2}(0001)$ template, and the $4 \mathrm{H}-\mathrm{SiC}$ (0001) substrate were determined from the $\varphi$-scans in Fig. 4 and GID in Fig. 3 to be

$$
\begin{aligned}
& \text { out of plane } \mathrm{r}-\mathrm{BN}(0001)\left\|\mathrm{ZrB}_{2}(0001)\right\| 4 \mathrm{H}-\mathrm{SiC}(0001) \\
& \text { in plane } \mathrm{r}-\mathrm{BN}[11 \overline{2} 0]\left\|\mathrm{ZrB}_{2}[1 \overline{1} 0]\right\| 4 \mathrm{H}-\mathrm{SiC}[11 \overline{2} 0] .
\end{aligned}
$$

These epitaxial relationships are similar to those previously determined for AlN (Ref. 20) and GaN (Refs. 18 and 23) films deposited by $\mathrm{CVD}$ on $\mathrm{ZrB}_{2}$ crystals. XRD $\varphi$-scans of sample 3 showed peaks at the same position with respect to the other layers, but their intensity was close to the background. This is consistent with XPS and the limited thickness suggested for sample 3.

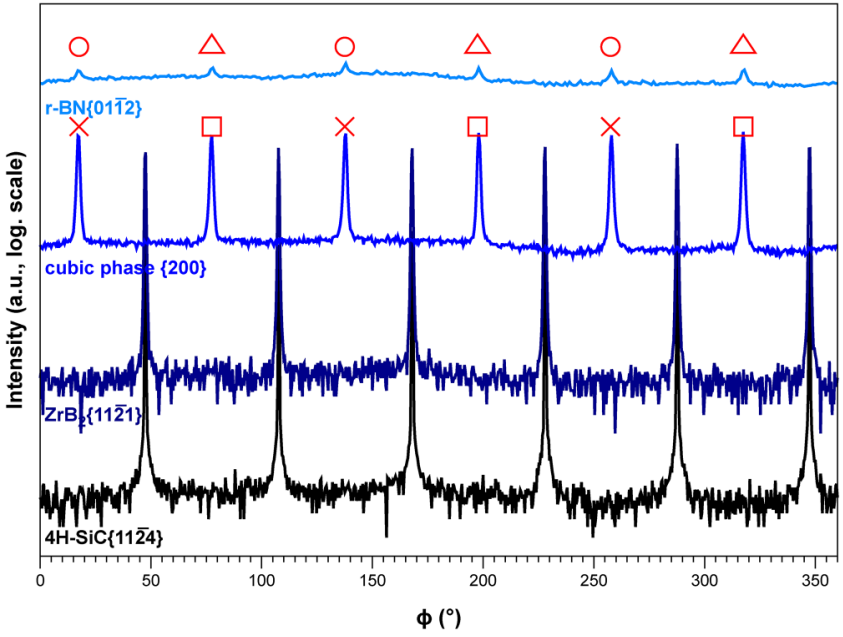

FIG. 4. XRD $\varphi$-scans of sample 2 showing the respective epitaxial relationships between each layer from top to bottom: $r-B N\{0112\},\{200\}$ for the cubic phase, $\mathrm{ZrB}_{2}\{11 \overline{2} 1\}$, and $4 \mathrm{H}-\mathrm{SiC}\{11 \overline{2} 4\}$. The twinning of $\mathrm{r}-\mathrm{BN}$ is illustrated by open circles and triangles, while of the twinning of the cubic phase is indicated by crosses and squares.

In addition, the diffractogram in Fig. 2 shows two broad peaks: a first order diffraction at $2 \theta=33.5^{\circ}$ and a second at $2 \theta=70.5^{\circ}$. Furthermore, GID in Fig. 3 and $\varphi$-scans in Fig. 4 show peaks that are consistent with the formation of an epitaxial, twinned, cubic interlayer. A thin interfacial layer between $13-\mathrm{N}$ semiconductor and $\mathrm{ZrB}_{2}$ that is typically referred to as $\mathrm{ZrB}_{\mathrm{x}} \mathrm{N}_{1-\mathrm{x}}$ (with $0<\mathrm{x}<1$ ) has been reported for growth of AlN (Ref. 20) and GaN (Refs. 21 and 22) on $\mathrm{ZrB}_{2}$ substrates. In these studies, it was determined from TEM that the $\mathrm{ZrB}_{\mathrm{x}} \mathrm{N}_{1-\mathrm{x}}$ layer exhibited an $\mathrm{NaCl}$ type structure and was about $2 \mathrm{~nm}$ thick after $1 \mathrm{~min}$ exposure to $\mathrm{NH}_{3}$ at $400{ }^{\circ} \mathrm{C}$ and about $9 \mathrm{~nm}$ thick after $1 \mathrm{~min}$ exposure at $1100^{\circ} \mathrm{C}^{21}$ In the present study, on the $2 \theta / \omega$ diffractogram in Fig. 2 , a broad peak is observed at around $33^{\circ}$, whose position is in agreement with the (111) planes of the $\mathrm{ZrB}_{\mathrm{x}} \mathrm{N}_{1-\mathrm{x}}$ phase observed in the aforementioned reports. The formation of a zirconium-containing cubic material with the $\mathrm{NaCl}$ structure (such as $\mathrm{ZrB}, \mathrm{ZrN}, \mathrm{ZrC}, \mathrm{ZrO}$, or solid solutions of these phases) is further supported by both GID and $\varphi$-scans, which suggest epitaxial relationships to $\mathrm{ZrB}_{2}$. Additionally, $\varphi$-scans show twinning of the cubic phase, which is expected from the higher symmetry of the hexagonal phases $\left(\mathrm{ZrB}_{2}, 4 \mathrm{H}-\mathrm{SiC}\right)$. It is not possible to confirm the composition and the location of this cubic phase from thin film XRD techniques; nevertheless, the broadening and intensity of the (111) peak in the $2 \theta / \omega$ diffractogram are consistent with the formation of a layer that is around $10 \mathrm{~nm}$ thick.

\section{Analytical transmission electron microscopy}

Figure 5(a) shows an overview TEM image of the sample 1 structure in cross section; $\mathrm{r}-\mathrm{BN}$ is found to grow on $\mathrm{ZrB}_{2}$ to an average thickness of about $\sim 10 \mathrm{~nm}$ beyond which epitaxial growth is either maintained to $\sim 80 \mathrm{~nm}$, corresponding to the total film 


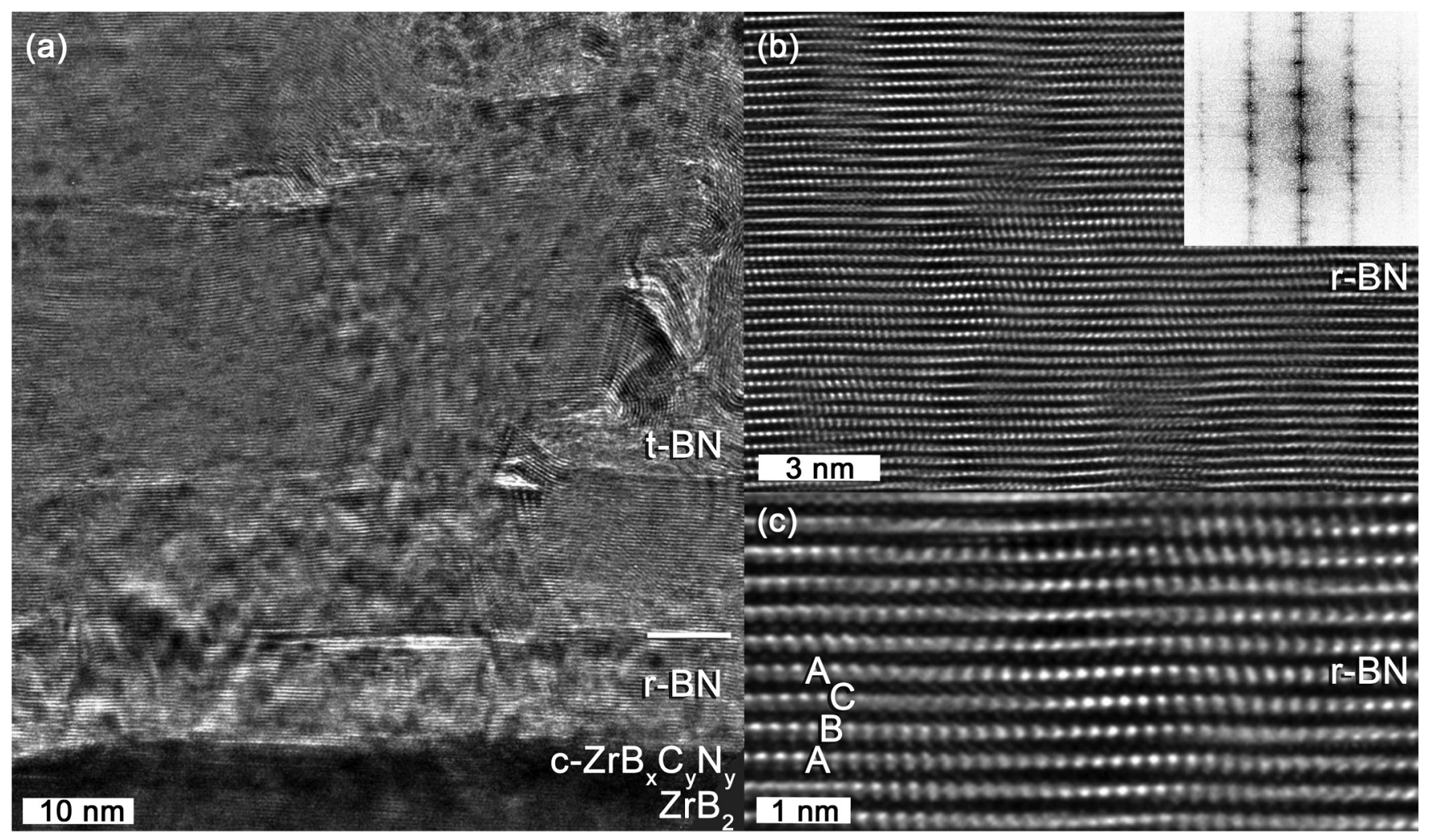

FIG. 5. Cross-sectional TEM images acquired from sample 1 showing (a) an overview of the $r-B N$ film deposited on the $\mathrm{ZrB}$ (0001) template. The film starts to evolve into t-BN after a thickness of $\sim 10 \mathrm{~nm}$. (b) and (c) r-BN film and its $A B C$ stacking at high magnification. The inset shows the fast Fourier transform (FFT) of the r-BN film.

thickness, or evolves to turbostratic $\mathrm{BN}(\mathrm{t}-\mathrm{BN})$ with a gradually increasing disorder. Figures 5(b) and 5(c) show higher magnification images and the corresponding FFT acquired from the r-BN layer. The image in Fig. 5(c) shows the ABCABCABC ... stacking sequence characteristic for $\mathrm{r}-\mathrm{BN}$ that is similar to that previously observed by Chubarov et al. in epitaxial growth of $\mathrm{r}-\mathrm{BN}$ on $\mathrm{Al}_{2} \mathrm{O}_{3}(0001)^{5}$ and $\left.6 \mathrm{H}-\mathrm{SiC}(0001)\right)^{7}$ Only the rhombohedral polytype was observed, which is consistent with the GID measurements.

The cubic phase that was mentioned in Sec. III B was observed at the $\mathrm{ZrB}_{2}$ surface as shown by the HRTEM images and the FFTs in Figs. 5(a) and 6(b). These inclusions were around $\sim 5 \mathrm{~nm}$ thick and only cover small areas of $\mathrm{ZrB}_{2}$ surface and do not disturb the growth of $\mathrm{r}-\mathrm{BN}$ as shown in Fig. 6(a). The epitaxial relationship between the inclusion and the $\mathrm{ZrB}_{2}$ template is illustrated on Fig. 6(b), which shows the lattices of each phase projected along the [1 12$]$ and [1010] directions, respectively. In addition, Fig. 6(a) shows an atomically sharp interface between a cubic $\mathrm{ZrB}_{\mathrm{x}} \mathrm{C}_{\mathrm{y}} \mathrm{N}_{\mathrm{z}}$ inclusion and the r-BN film. Figure 6(b) shows an atomically sharp interface between the cubic $\mathrm{ZrB}_{\mathrm{x}} \mathrm{C}_{\mathrm{y}} \mathrm{N}_{\mathrm{z}}$ inclusion and the $\mathrm{ZrB}_{2}$ template. EELS areal maps and line profiles (Fig. 7) confirmed that these inclusions are boron deficient and incorporate carbon and nitrogen. These inclusions will be referred to as $\mathrm{ZrB}_{\mathrm{x}} \mathrm{C}_{\mathrm{y}} \mathrm{N}_{\mathrm{z}}$.

\section{Surface morphology}

The surface morphology of the epitaxial $r-B N$ films was found to be dependent on the duration of the pretreatment in $\mathrm{H}_{2}-\mathrm{SiH}_{4}$, see top view SEM images in Fig. 8. As can be seen, the samples 1, 2, and 3 display surfaces covered by smooth triangular grains surrounded by a rough disordered material. This type of surface structure has previously been observed for r-BN epitaxy $\alpha-\mathrm{Al}_{2} \mathrm{O}_{3}$ from TEB and $\mathrm{NH}_{3}$ at $1500{ }^{\circ} \mathrm{C}$ (Ref. 46) and is consistent with our thin film XRD results and cross-sectional TEM observations. Furthermore, the SEM images show the twinning of the crystals, as can be seen in the right upper corner in Fig. 8(a). This is characteristic for epitaxial growth of $\mathrm{r}-\mathrm{BN}$ on hexagonal substrates and buffer layers.

\section{E. BN growth on $\mathrm{ZrB}_{2}(0001)$}

From the SEM images in Fig. 8, we observed that the surface was dominated by disordered material and with only a few crystals visible. Analysis by XPS showed that this disordered material exhibited a B-rich composition $(1.20<\mathrm{B} / \mathrm{N}<1.30)$ and contained 10 at. \% $\mathrm{C}$ (see Table I). The fact that the majority phase at the surface is a disordered material and hence $\mathrm{x}$-ray amorphous together with the previous described limitation of XPS following sputter-cleaning 

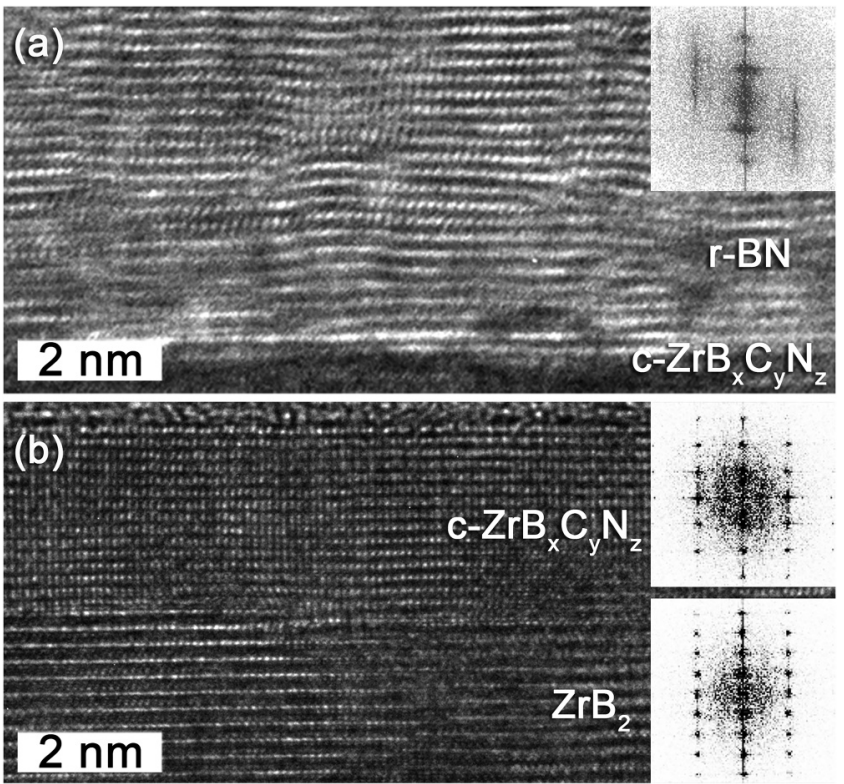

FIG. 6. HRTEM images acquired from sample 1 showing (a) the initial $r-B N$ layer grown onto the cubic $\mathrm{ZrB}_{x} \mathrm{C}_{y} \mathrm{~N}_{z}$ inclusion. The inset shows the FFT from initial $r-B N$ film. (b) The cubic $\mathrm{ZrB}_{x} \mathrm{C}_{y} \mathrm{~N}_{z}$ inclusion formed onto the $\mathrm{ZrB}_{2}$ template with its respective FFT.

explain the apparent discrepancies between XPS and XRD. These observations are supported by TEM that showed that the films are more crystalline toward the substrate [Fig. 5(a)] and the EELS profile in Fig. 7 indicating an increase in carbon content from the
$\mathrm{ZrB}_{\mathrm{x}} \mathrm{C}_{\mathrm{y}} \mathrm{N}_{\mathrm{z}}$ interface to the surface. This suggests that the crystal quality of the deposited $\mathrm{r}-\mathrm{BN}$ films is affected by carbon.

\section{F. Stability of $\mathrm{ZrB}_{2}$ in CVD of $\mathrm{sp}^{2}-\mathrm{BN}$}

The results from studies conducted on $\mathrm{ZrB}_{2}$ substrates show high thermal and chemical stability of the boride, which allow the substrate to resist conditions typical for CVD processing of $\mathrm{sp}^{2}-\mathrm{BN}$.

As our CVD process is based on the reaction of an organoboron with $\mathrm{NH}_{3}$ in hydrogen ambient, we put this present work in the context of studies involving annealing of $\mathrm{ZrB}_{2}$ in $\mathrm{H}_{2}$ and the ones focusing on B-containing compound CVD on $\mathrm{ZrB}_{2}$ or group 13 nitrides on $\mathrm{ZrB}_{2}$. The study by Tomida et al. ${ }^{21}$ showed that annealing in hydrogen up to $1100^{\circ} \mathrm{C}$ did not affect the $\mathrm{ZrB}_{2}$ surface. At a higher temperature of $1200^{\circ} \mathrm{C}$, Padavala et al. ${ }^{26}$ deposited semiconductor $\mathrm{BP}$ films from diborane $\left(\mathrm{B}_{2} \mathrm{H}_{6}\right)$ and phosphine $\left(\mathrm{PH}_{3}\right)$ at $1200{ }^{\circ} \mathrm{C}$ and without apparent change to $\mathrm{ZrB}_{2}$ template. The presence of $\mathrm{NH}_{3}$ is known to result in the partial nitridation of the surface as seen from the $\mathrm{ZrB}_{\mathrm{x}} \mathrm{N}_{1-\mathrm{x}}$ interlayer reported for AlN and GaN growth. ${ }^{20-22}$ The nitridation of the surface still allowed to obtain an abrupt interface between the film and the substrate.

Compared with these previous works, our CVD process is performed at a higher temperature $\left(1485^{\circ} \mathrm{C}\right)$ and involves $\mathrm{SiH}_{4}$, which has already been reported to aggressively etch thermally stable materials such as rhombohedral boron carbide. ${ }^{47}$ Interestingly, the use of higher growth temperatures than for the deposition of $\mathrm{GaN}$ or AlN did not result in the formation of a $\mathrm{ZrB}_{\mathrm{x}} \mathrm{N}_{1-\mathrm{x}}$ interlayer but of a few $\mathrm{ZrB}_{\mathrm{x}} \mathrm{C}_{\mathrm{y}} \mathrm{N}_{\mathrm{z}}$ inclusions instead. The fact that the amount of the $\mathrm{ZrB}_{\mathrm{x}} \mathrm{C}_{\mathrm{y}} \mathrm{N}_{\mathrm{z}}$ phase is low may be an indication that $\mathrm{r}-\mathrm{BN}$ rapidly covers the surface of the $\mathrm{ZrB}_{2}$ template in the early stage of the growth and acts as a diffusion barrier for both $\mathrm{N}$ and $\mathrm{C}$.

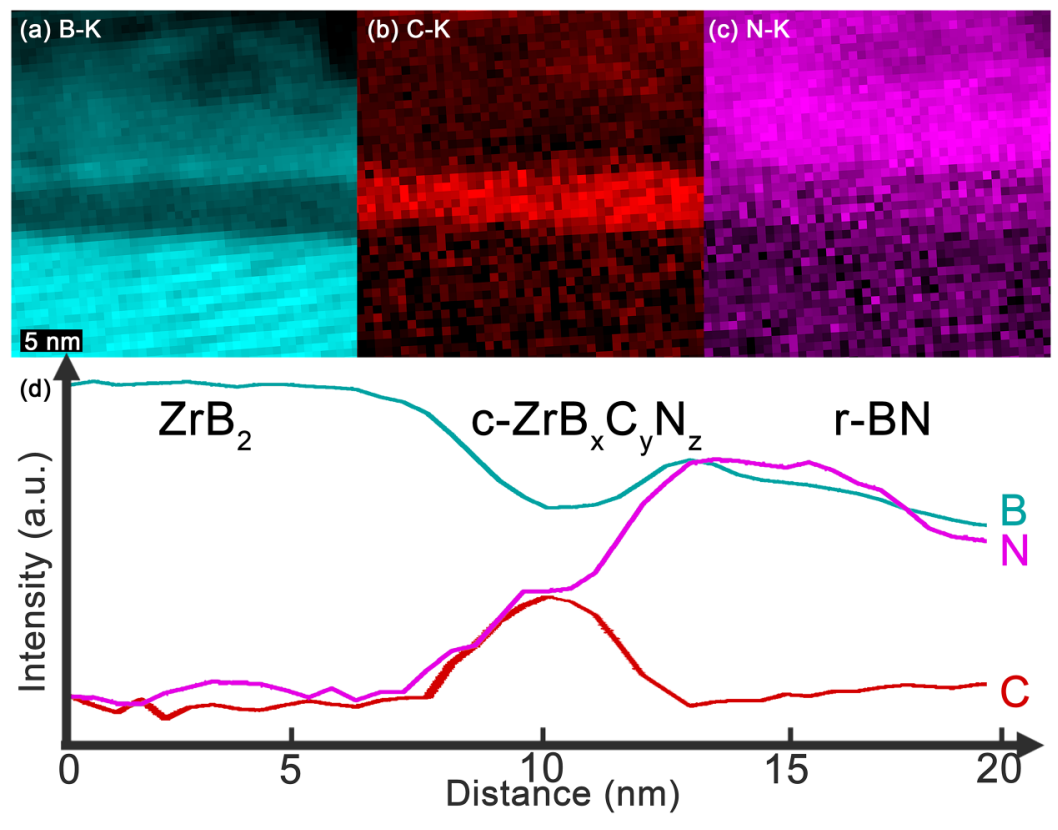

FIG. 7. Background-subtracted and integrated (a) B-K (188-200 eV), (b) C-K (284-310 eV), and (c) N-K (401$430 \mathrm{eV}$ ) EELS edge intensity distribution maps, and (d) line profiles acquired from the cubic $\mathrm{ZrB}_{x} \mathrm{C}_{y} \mathrm{~N}_{z}$ inclusion formed on $\mathrm{ZrB}_{2}$. 


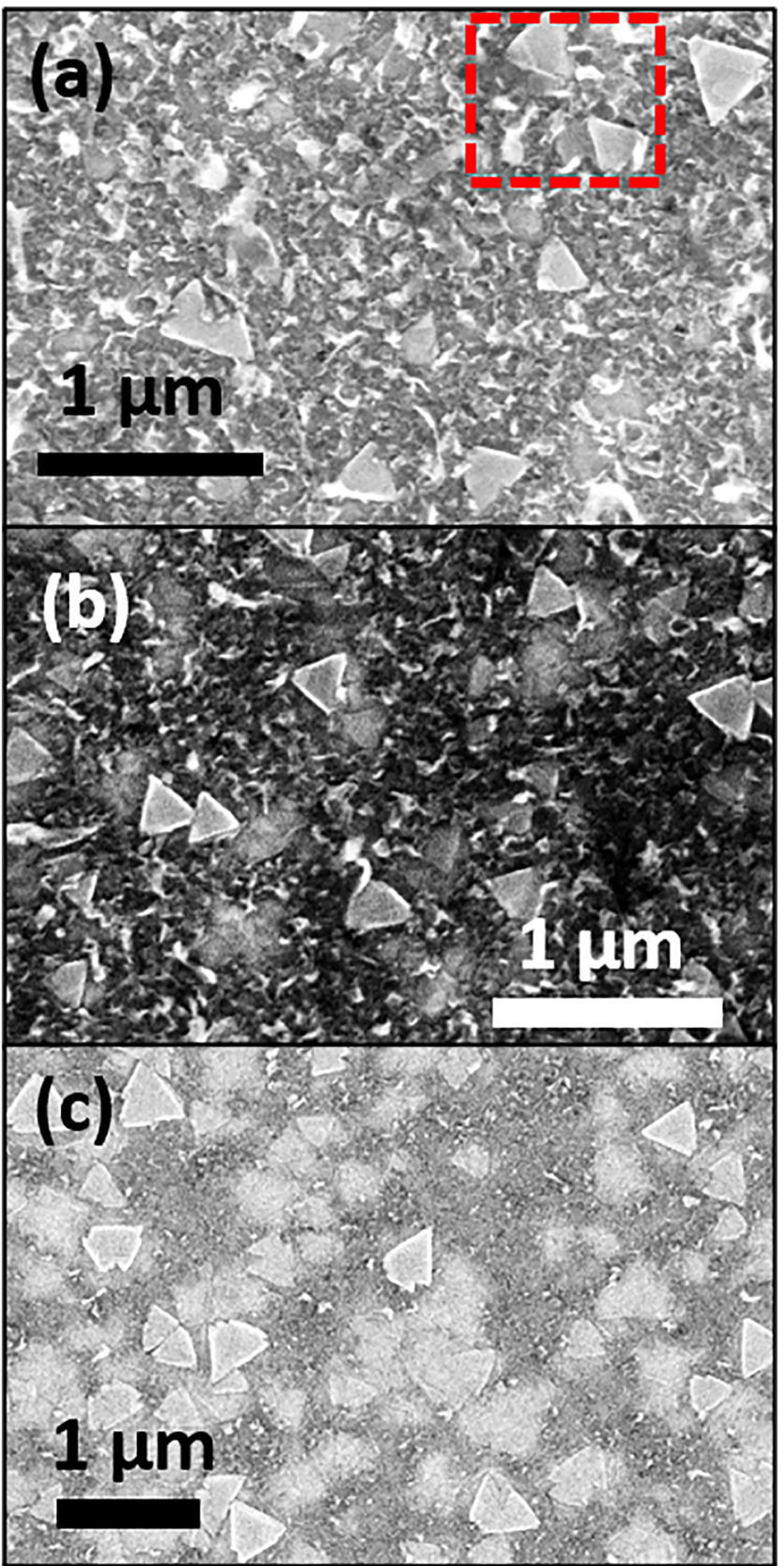

FIG. 8. Plan-view SEM images with sample 1 in (a), sample 2 in (b), and sample 3 in (c). Twinning of the r-BN crystals is visible in the dashed rectangle the upper right part of the image in (a)

\section{CONCLUSIONS}

We report epitaxial growth of $r-B N$ films by CVD on $\mathrm{ZrB}_{2}(0001)$ templates from the reaction of TEB and $\mathrm{NH}_{3}$ in an $\mathrm{H}_{2}$ ambient at $7000 \mathrm{~Pa}$ and $1485^{\circ} \mathrm{C}$. High-resolution analytical microscopy shows that the epitaxial $\mathrm{BN}$ layer grows uniformly to a thickness of about $10 \mathrm{~nm}$, beyond which disordered growth is initiated and epitaxial growth proceeds locally up to $80 \mathrm{~nm}$. The r-BN layers nucleate directly on the $\mathrm{ZrB}_{2}(0001)$ surface and with areas with nucleation of $\mathrm{r}-\mathrm{BN}$ on a quaternary cubic compound $\mathrm{ZrB}_{\mathrm{x}} \mathrm{C}_{\mathrm{y}} \mathrm{N}_{\mathrm{z}}$. Thin film XRD supports the growth of $\mathrm{r}-\mathrm{BN}$ and the formation of $\mathrm{ZrB}_{\mathrm{x}} \mathrm{C}_{\mathrm{y}} \mathrm{N}_{\mathrm{z}}$. GID and $\mathrm{XRD} \varphi$-scans show that the out-of-plane epitaxial relationship is $r-\mathrm{BN}(0001) \| \mathrm{ZrB}_{2}$ (0001) and the in-plane epitaxial relationship is $\mathrm{r}-\mathrm{BN}[11 \overline{2} 0] \| \mathrm{ZrB}_{2}$ [1120]. XPS and SEM show that prolonged pretreatment in $\mathrm{H}_{2}-\mathrm{SiH}_{4}$ has a positive influence on the epitaxial growth of $\mathrm{r}-\mathrm{BN}$, as shown by the $\mathrm{B} / \mathrm{N}$ ratio at the film surface decreasing from 1.3 to 1.2 and the increased coverage of the surface by $\mathrm{r}-\mathrm{BN}$ crystallites. Our study is promising for the prospect of realizing the growth of 13-15 semiconductor materials such as $\mathrm{r}-\mathrm{BN}$ on transition metal diborides.

\section{ACKNOWLEDGMENTS}

The authors would like to acknowledge Lina Tengdelius and Claudia Schnitter for depositing the epitaxial $\mathrm{ZrB}_{2}$ films, Polla Rouf for the XPS measurements, and Melike Mercan Yildizhan Özyar and Samira Dorri for TEM sample preparation. This work was supported by the Swedish Foundation for Strategic Research (SSF), Contract No. IS14-0027, and Carl Trygger's Foundation for Scientific Research, Contract No. CTS 14:189. H.P. and H.H. acknowledge financial support from the Swedish Government Strategic Research Area in Materials Science on Functional Materials at Linköping University (Faculty Grant SFO-Mat-LiU No. 2009-00971). The authors acknowledge the Knut and Alice Wallenberg Foundation for support of the electron microscopy laboratory in Linköping.

\section{DATA AVAILABILITY}

The data that support the findings of this study are available within the article and its supplementary material. ${ }^{48}$

\section{REFERENCES}

${ }^{1}$ K. Watanabe, T. Taniguchi, and H. Kanda, Nat. Mater. 3, 404 (2004).

${ }^{2}$ T. Takahashi, H. Itoh, and M. Kuroda, J. Cryst. Growth 53, 418 (1981).

${ }^{3}$ H. Hannache, R. Naslain, and C. Bernard, J. Less Common Met. 95, 221 (1983).

${ }^{4}$ T. Matsuda, N. Uno, H. Nakae, and T. Hirai, J. Mater. Sci. 21, 649 (1986).

${ }^{\mathbf{5}}$ M. Chubarov, H. Pedersen, H. Högberg, V. Darakchieva, J. Jensen, P. O. Å. Persson, and A. Henry, Phys. Status Solidi RRL 5, 397 (2011).

${ }^{\mathbf{6}} \mathrm{M}$. Chubarov, H. Pedersen, H. Högberg, J. Jensen, and A. Henry, Cryst. Growth Des. 12, 3215 (2012).

${ }^{7}$ M. Chubarov, H. Pedersen, H. Högberg, Z. Czigany, and A. Henry, CrystEngComm 16, 5430 (2014).

${ }^{8}$ N. Umehara, A. Masuda, T. Shimizu, I. Kuwahara, and T. Kouno, Jpn. J. Appl. Phys. 55, 05FD09 (2016).

${ }^{9}$ L. Souqui, H. Pedersen, and H. Högberg, J. Vac. Sci. Technol. A 37, 020603 (2019).

${ }^{10}$ R. Kiessling, Acta Chem. Scand. 3, 90 (1949).

${ }^{11}$ W. G. Fahrenholtz, G. E. Hilmas, I. G. Talmy, and J. A. Zaykoski, J. Am. Ceram. Soc. 90, 1347 (2007).

${ }^{12}$ H. J. Juretschke and R. Steinitz, J. Phys. Chem. Solids 4, 118 (1958).

${ }^{13}$ R. C. Linton, Thin Solid Films 20, 17 (1974).

${ }^{14}$ L. Tengdelius, E. Broitman, J. Lu, F. Eriksson, J. Birch, T. Nyberg, L. Hultman, and H. Högberg, Acta Mater. 111, 166 (2016). 
${ }^{15}$ L. Tengdelius, J. Birch, J. Lu, L. Hultman, U. Forsberg, E. Janzén, and H. Högberg, Phys. Status Solidi A 211, 636 (2014).

${ }^{16}$ L. Tengdelius, G. Greczynski, M. Chubarov, J. Lu, U. Forsberg, L. Hultman, E. Janzén, and H. Högberg, J. Cryst. Growth 430, 55 (2015).

${ }^{17}$ H. Kinoshita, S. Otani, S. Kamiyama, H. Amano, I. Akasaki, J. Suda, and H. Matsunami, Jpn. J. Appl. Phys. 40, L1280 (2001); available at https:// iopscience.iop.org/article/10.1143/JJAP.40.L1280.

18. Suda and H. Matsunami, J. Cryst. Growth 237-239, 1114 (2002).

${ }^{19}$ X. C. Wu, R. Q. Cai, P. X. Yan, W. M. Liu, and J. Tian, Appl. Surf. Sci. 185, 262 (2002).

${ }^{20}$ R. Liu, A. Bell, F. A. Ponce, S. Kamiyama, H. Amano, and I. Akasaki, Appl. Phys. Lett. 81, 3182 (2002).

${ }^{21}$ Y. Tomida et al., Appl. Surf. Sci. 216, 502 (2003).

${ }^{22}$ H. Kinoshita, S. Otani, S. Kamiyama, H. Amano, I. Akasaki, J. Suda, and H. Matsunami, Jpn. J. Appl. Phys. 42, 2260 (2003).

${ }^{23}$ Y. Kawaguchi, J. Ohta, A. Kobayashi, and H. Fujioka, Appl. Phys. Lett. 87, 221907 (2005).

${ }^{24} \mathrm{~J}$. Tolle, R. Roucka, I. S. T. Tsong, C. Ritter, P. A. Crozier, A. V. G. Chizmeshya, and J. Kouvetakis, Appl. Phys. Lett. 82, 2398 (2003).

${ }^{25}$ Z. T. Wang, Y. Yamada-Takamura, Y. Fujikawa, T. Sakurai, Q. K. Xue, J. Tolle, J. Kouvetakis, and I. S. T. Tsong, J. Appl. Phys. 100, 033506 (2006).

${ }^{26}$ B. Padavala, H. Al Atabi, L. Tengdelius, J. Lu, H. Högberg, and J. H. Edgar, J. Cryst. Growth 483, 115 (2018).

${ }^{\mathbf{2 7}}$ A. Küper, G. Kehr, J. Pflug, C. Sarter, P. Mayr, and G. Erker, Surf. Eng. 17, 55 (2001).

${ }^{28}$ R. R. Q. Freitas, G. K. Gueorguiev, F. De Brito Mota, C. M. C. De Castilho, S. Stafström, and A. Kakanakova-Georgieva, Chem. Phys. Lett. 583, 119 (2013).

${ }^{29} \mathrm{M}$. Chubarov, H. Pedersen, H. Högberg, Z. Czigány, M. Garbrecht, and A. Henry, Chem. Mater. 27, 1640 (2015).

${ }^{\mathbf{3 0}} \mathrm{M}$. Chubarov, H. Pedersen, H. Högberg, and A. Henry, CrystEngComm 15, 455 (2013).
${ }^{31}$ S. Hüfner, Photoelectron Spectroscopy: Principles and Applications, 3rd ed. (Springer-Verlag, Berlin, 2010).

${ }^{32}$ J. F. Moulder, W. F. Stickle, P. E. Sobol, and K. D. Bomben, Handbook of $X$-Ray Photoelectron Spectroscpopy (Perkin-Elmer Corporation, Eden Prairie, MN, 1992).

${ }^{33}$ S. Hofmann, Auger- and X-Ray Photoelectron Spectroscopy in Materials Science: A User-Oriented Guide, edited by G. Ertl, H. Lüth, and D. L. Mills (Springer-Verlag, Berlin, 2013).

${ }^{34}$ C. L. Jia, M. Lentzen, and K. Urban, Microsc. Microanal. 10, 174 (2004).

${ }^{35}$ R. Trehan, Y. Lifshitz, and J. W. Rabalais, J. Vac. Sci. Technol. A 8, 4026 (1990).

${ }^{36}$ T. Aizawa, S. Suehara, S. Hishita, S. Otani, and M. Arai, Phys. Rev. B 71, 165405 (2005).

${ }^{37}$ W. E. Moddeman, A. Burke, W. C. Bowling, and D. S. Foose, Interface 14, 224 (1989).

${ }^{38}$ S. Jacques, A. Guette, X. Bourrat, F. Langlais, C. Guimon, and C. Labrugere, Carbon 34, 1135 (1996).

${ }^{39}$ M. Koh and T. Nakajima, Carbon 36, 913 (1998).

${ }^{40}$ T. Shirasaki, A. Derré, M. Ménétrier, A. Tressaud, and S. Flandrois, Carbon 38, 1461 (2000).

${ }^{41}$ W. Cermignani, T. E. Paulson, C. Onneby, and C. G. Pantano, Carbon 33, 367 (1995).

${ }^{42}$ G. Greczynski, D. Primetzhofer, J. Lu, and L. Hultman, Appl. Surf. Sci. 396, 347 (2017).

${ }^{43}$ D. Belforti, B. Bovarnick, and S. Blum, Nature 190, 901 (1961).

${ }^{44}$ R. S. Pease, Acta Crystallogr. 5, 356 (1952).

${ }^{45}$ T. Sato, Proc. Jpn. Acad. Ser. B Phys. Biol. Sci. 61, 459 (1985).

${ }^{46}$ M. Chubarov, H. Pedersen, H. Högberg, S. Filippov, J. A. A. Engelbrecht, J. O'Connel, and A. Henry, Physica B 439, 29 (2014).

${ }^{47}$ L. Souqui, H. Pedersen, and H. Högberg, J. Vac. Sci. Technol. A 38, 043402 (2020).

${ }^{48}$ See supplementary material at https://doi.org/10.1116/6.0000571 for $2 \theta / \omega$ diffractogram. 